\title{
GROWTH AND NUTRITION OF EUCALYPT ROOTED CUTTINGS PROMOTED BY ECTOMYCORRHIZAL FUNGI IN COMMERCIAL NURSERIES
}

\author{
Andrezza Mara Martins Gandini(1), Paulo Henrique Grazziotti ${ }^{(2)}$, Márcio José Rossi ${ }^{(3)}$, \\ Danielle Cristina Fonseca Santos Grazziotti(1), Elizzandra Marta Martins Gandini(1), Enilson \\ de Barros Silva ${ }^{(4)}$ and Carla Ragonezi ${ }^{(1)}$ \\ (1) Universidade Federal dos Vales do Jequitinhonha e Mucuri, Programa de Pós-graduação em Produção Vegetal, Diamantina, \\ Minas Gerais, Brasil. \\ (2) Universidade Federal dos Vales do Jequitinhonha e Mucuri, Departamento de Engenharia Florestal, Faculdade de Ciências \\ Agrárias, Diamantina, Minas Gerais, Brasil. \\ (3) Universidade Federal de Santa Catarina, Departamento de Microbiologia, Imunologia e Parasitologia, Florianópolis, Santa \\ Catarina, Brasil. \\ (4) Universidade Federal dos Vales do Jequitinhonha e Mucuri, Departamento de Agronomia, Faculdade de Ciências Agrárias, \\ Diamantina, Minas Gerais, Brasil. \\ * Corresponding author. \\ E-mail: grazziot@yahoo.com.br
}

\begin{abstract}
Ectomycorrhizal fungi (EMF) may improve the adaptation of eucalypts saplings to field conditions and allow more efficient fertilizer use. The effectiveness of EMF inoculum application in promoting fungal colonization, plant growth, nutrient uptake, and the quality of rooted cuttings was evaluated for Eucalyptus urophylla under commercial nursery conditions. For inoculated treatments, fertilization of the sapling substrate was reduced by $50 \%$. The experiment was carried out in a completely randomized design in a $4 \times 4$ factorial arrangement, wherein the factors were inoculum application rates of 0 (control), 5, 10, and 15 gel beads of calcium alginate containing the vegetative mycelium of Amanita muscaria, Elaphomyces antracinus, Pisolithus microcarpus, and Scleroderma areolatum, plus a non-inoculated treatment without fertilization reduction in the substrate (commercial). Ectomycorrhizal fungi increased plant growth and fungal colonization as well as $\mathrm{N}$ and $\mathrm{K}$ uptake evenly. The best plant growth and fungal colonization were observed for the highest application rate. The greatest growth and fungal colonization and contents of $P, N$, and $K$ were observed at
\end{abstract}




\begin{abstract}
the 10-bead rate. Plant inoculation with Amanita muscaria, Elaphomyces anthracinus, and Scleroderma areolatum increased $P$ concentrations and contents in a differential manner. The Dickson Quality Index was not affected by the type of fungi or by inoculum application rates. Eucalypt rooted cuttings inoculated with ectomycorrhizal fungi and under half the amount of commercial fertilization had $P, N$, and $K$ concentrations and contents greater than or equal to those of commercial plants and have high enough quality to be transplanted after 90 days.
\end{abstract}

Keywords: symbiosis, plant nutrition, cuttings production, phosphorus, nitrogen, potassium.

\title{
RESUMO: CRESCIMENTO E NUTRIÇÃO DE MUDAS CLONAIS DE EUCALIPTO PROMOVIDOSPOR FUNGOS ECTOMICORRÍZICOS EMVIVEIROSCOMERCIAIS
}

\begin{abstract}
A utilização dos fungos ectomicorrízicos (FEM) em eucalipto pode melhorar a adaptação das mudas no campo e permitir um uso mais eficiente de fertilizantes. A eficiência de doses de inoculante de FEM em promover a colonização ectomicorrízica, o crescimento, a absorção de nutrientes e a qualidade de mudas clonais de Eucalyptus urophylla foi avaliada em condições de viveiro comercial. Para os tratamentos com doses de inoculante, a adubação de substrato de produção das mudas foi reduzida em $50 \%$. O experimento foi realizado em delineamento inteiramente casualizado em esquema fatorial $4 \times 4$, sendo: as doses 0 (controle), 5, 10 e 15 esferas de gel de alginato de cálcio contendo micélio vegetativo de Amanita muscaria, Elaphomyces antracinus, Pisolithus microcarpus e Scleroderma areolatum, mais um tratamento não inoculado sem redução da fertilização de substrato (Comercial). Os FEM aumentaram o crescimento, a colonização e a absorção de $\mathrm{Ne}$ K de forma igual. O melhor crescimento e colonização foram observados na maior dose de inoculante; e os maiores teores e conteúdos de P, N e K, na dose de 10 esferas. A inoculação das mudas clonais com Amanita muscaria, Elaphomyces anthracinus e Scleroderma areolatum aumenta de forma diferenciada os teores e conteúdos de P. O índice de qualidade de Dickson não foi influenciado pelos fungos e nem pelas doses de inóculo. As mudas clonais de eucalipto inoculadas pelos FEMe crescidas com a metade da adubação de substrato apresentaram teores e conteúdos de P e Ne teor de K maiores ou iguais àquelas do Comercial e qualidade suficiente para o transplantio aos 90 dias.
\end{abstract}

Palavras-chave: simbiose, nutrição de plantas, produção de mudas, fósforo, nitrogênio, potássio.

\section{INTRODUCTION}

Ectomycorrhizal symbiosis is common in Brazilian large-scale eucalypts plantations. However, it is rare in forest plant nurseries due to high $\mathrm{P}$ and $\mathrm{N}$ fertilizations (Soares et al., 1990) and the use of inert substrates such as vermiculite, carbonized rice husk, and coconut fiber, which are devoid of ectomycorrhizal fungi (EMF). Despite decades of studies, fungal inoculation procedures in commercial plantations have not been established for Brazilian conditions. The lack of suitable ectomycorrhizal inocula on the market is one of the main factors that contributes to this situation (Rossi et al., 2007).

Ectomycorrhizal fungi bring benefits to plants as they enhance growth, nutrient uptake, and biotic and abiotic stress tolerance (Grazziotti et al., 2003; Aggangan et al., 2010; Sousa et al., 2012; Targhetta et al., 2013; Fernandes et al., 2014). Ectomycorrhizal fungi used in commercial eucalypts plantations have been considered an alternative for improving fertilizer uptake, making saplings more resistant to pathogens, and increasing survival performance after transplanting (Chen et al., 2006a; Souza et al., 2012), especially in low fertility soils.
Ectomycorrhizal fungi inoculation studies show that results vary according to the host plant, inoculum type, fertilizer rates, and fungal isolate or EMF species (Garbaye, 1990; Oliveira et al., 2006). Chinese studies on eucalypts seedlings demonstrated that colonization intensity differs among 15 spore collections of Scleroderma, but only two of them form mycorrhizae over more than $50 \%$ of fine roots in Eucalyptus urophylla and four in Eucalyptus globulus (Chen et al., 2006c). The authors observed a total dry matter increase up to 1.6 times for E. urophylla and two times for $E$. globulus compared to non-inoculated seedlings. Chondrogaster angustisporus and Pisolithus microcarpus vegetative inoculum in Eucalyptus dunnii increased the percent colonized root length, $\mathrm{P}$ uptake and shoot dry mass (SDM) of colonized plants (Souza et al., 2004). E. dunnii inoculated with Pisolithus sp., grown in a mixture with vermiculitepeat culture medium, had greater colonization at the highest inoculum rate (10\% in sapling substrate), whereas shoot height, diameter, and SDM increases were observed as of a $3 \%$ inoculum rate and greater $\mathrm{P}$ concentrations as of $1 \%$ (Alves et al., 2001).

The vast majority of studies assess the effects of EMF inoculation under controlled conditions, 
especially in greenhouses (Courty et al., 2010) and with seminal saplings (Alves et al., 2001; Souza et al., 2004; Chen et al., 2006c). The development of this biotechnology for routine inoculation in commercial nurseries may increase the sustainability of planted forests in Brazil, making the already competitive forestry sector even more competitive. This may also reduce dependence on limited sources of phosphate fertilizers, which could be targeted to food production. The objective of this study was to evaluate the efficiency of application rates of ectomycorrhizal fungal inocula on promoting mycorrhizal colonization, plant growth, nutrient uptake, and quality of Eucalyptus urophylla rooted cuttings under commercial nursery conditions.

\section{MATERIAL AND METHODS}

\section{Nursery description}

The study was carried out in a commercial nursery of eucalypts saplings located in Itamarandiba, MG, Brazil. The average annual temperature is $20.1^{\circ} \mathrm{C}$, the average minimum is $15^{\circ} \mathrm{C}$ and the average maximum is $26.1^{\circ} \mathrm{C}$; the average temperature of the warmest month is $23.8^{\circ} \mathrm{C}$. Average annual pluvial precipitation is $1081.1 \mathrm{~mm}$, and the rainy season occurs from October to March and represents $89 \%$ of the total rainfall for the year (INMET, 2009). The climate is high-altitude tropical - Cfa (Köppen, 1918).

\section{Experimental design}

The experiment was carried out in a completely randomized design in a $4 \times 4$ factorial arrangement plus an additional treatment, with four replications. The experimental plot was composed of 40 saplings of the natural hybrid of Eucalyptus urophylla S.T. Blake; the 18 central plants were considered for sampling. Factors were application rate and EMF species, with four variations each: zero (control), 5, 10, and 15 gel beads of calcium alginate with vegetative mycelia of Amanita muscaria (L.) Lam., Scleroderma areolatum Ehrenb., Pisolithus microcarpus (Cooke \& Massee) G. Cunn., and Elaphomyces anthracinus Vittad. (Cenococcum geophilum Fr.). For the inoculated treatments, commercial fertilization in the substrate was reduced by $50 \%$ to prevent an inhibitory effect on ectomycorrhizal colonization. The additional treatment was non-inoculated rooted cuttings without substrate fertilization reduction (commercial). The commercial treatment was included so we could compare the results from ECM application to what has been successfully done for many years in reforestation companies.

\section{Fungal isolates and inoculum production}

The fungal isolates used were UFSC-Am161 of A. muscaria, UFSC-Sc129 of $S$. areolatum, ITA-06 of
P. microcarpus, and Amance of E. anthracinus. The first three were sampled from eucalypts plantations. A. muscaria (UFSC-Am161) was obtained from a Eucalyptus viminalis plantation and $S$. areolatum (UFSC-Sc129) from E. dunnii, both from the state of Santa Catarina, Brazil. P. microcarpus (ITA-06) was obtained in eucalypts plantations from the State of Minas Gerais, Brazil, and E. anthracinus (Amance) was obtained from a Fagus sylvatica plantation in France, which is generally considered dominant in natural ecosystems.

Fungi were grown in a liquid PGKM (Kuek, 1996) culture medium under submerged conditions (Rossi et al., 2007). After cultivation, mycelium was homogenized at 3,600 rpm and inserted into $4 \mathrm{~mm}$ gel beads of calcium alginate. Inocula were produced at the Laboratory of Bioprocesses of the Universidade Federal de Santa Catarina, where they went through feasibility tests. After $100 \%$ viability, 50 beads of each inoculum were sent to the Universidade Federal dos Vales do Jequitinhonha e Mucuri for plant experiments.

\section{Substrate production for rooted cuttings}

The substrate used for all treatments was composed of a mixture of vermiculite, carbonized rice husk, and coconut fiber at a 2:1:1 (v:v:v) ratio. This substrate is relatively inert in terms of readily available nutrients for plants. Routine nursery fertilization was used for the commercial treatment and consisted of $205 \mathrm{mg} \mathrm{dm}{ }^{-3} \mathrm{~N}$ and $456.4 \mathrm{mg} \mathrm{dm}^{-3} \mathrm{P}$ (11.9N-60.8P-00K,MAP); $95 \mathrm{mg} \mathrm{dm}^{-3} \mathrm{~N}, 13.1 \mathrm{mg} \mathrm{dm}^{-3} \mathrm{P}$, and $41.5 \mathrm{mg} \mathrm{dm}^{-3} \mathrm{~K}$ [19N-06P-10K slow-release (3 months), Osmocote $\left.{ }^{\circledR}\right] ; 41 \mathrm{mg} \mathrm{dm}^{-3} \mathrm{Mg}$ (Magnesium sulfate heptahydrate - with $9 \% \mathrm{Mg}$ ); $360 \mathrm{mg} \mathrm{dm}^{-3} \mathrm{~K}$ (Potassium chloride - $62 \% \mathrm{~K}$ ); $143 \mathrm{mg} \mathrm{dm} \mathrm{dm}^{-3} \mathrm{Ca}$ (Calcium chloride - $27 \% \mathrm{Ca}$ ); $1.56 \mathrm{mg} \mathrm{dm}^{-3} \mathrm{Fe}$ (Fe chelate for fertirrigation Ferrilene ${ }^{\circledR}-6 \% \mathrm{Fe}$ ); $2 \mathrm{mg} \mathrm{dm}^{-3} \mathrm{~B}$ (Boric acid - $17 \% \mathrm{~B}$ ); $1 \mathrm{mg} \mathrm{dm}^{-3} \mathrm{Cu}$ (Copper sulfate - $35 \% \mathrm{Cu}$ ); $5 \mathrm{mg} \mathrm{dm}^{-3} \mathrm{Mn}$ (Manganese sulfate $-30 \% \mathrm{Mn}$ ); and $1 \mathrm{mg} \mathrm{dm}{ }^{-3} \mathrm{Zn}$ (Zinc sulfate heptahydrate - $20 \% \mathrm{Zn}$ ). For inoculated treatments, including the control, these amounts of substrate fertilizers were reduced by $50 \%$.

Chemical composition of the substrate with half the amount of fertilizer was analyzed according to Embrapa (2011): $\mathrm{pH}\left(\mathrm{H}_{2} \mathrm{O}\right)$ 7.3; Carbon organic $132.3 \mathrm{~g} \mathrm{~kg}^{-1} ; \mathrm{N} 6.1 \mathrm{~g} \mathrm{~kg}^{-1} ; \mathrm{P} 372.4 \mathrm{mg} \mathrm{dm}{ }^{-3}$; $\mathrm{K} 1.85 \mathrm{mg} \mathrm{dm}^{-3} ; \mathrm{Ca}^{2+} 5.7 \mathrm{cmol}_{\mathrm{c}} \mathrm{dm}^{-3} ; \mathrm{Mg}^{2+} 1.3 \mathrm{cmol}_{\mathrm{c}} \mathrm{dm}^{-3}$; $\mathrm{Al}^{3+} 0.1 \mathrm{mg} \mathrm{dm}^{-3}$; effective cation-exchange capacity $11.8 \mathrm{cmol}_{\mathrm{c}} \mathrm{dm}^{-3}$; cation-exchange capacity at pH $712.9 \mathrm{cmol}_{\mathrm{c}} \mathrm{dm}^{-3}$; Al saturation $1 \%$; and base saturation $91 \%$.

\section{Inoculation, planting of mini-cuttings, and experimental maintenance fertilization}

Tubes with a volume of $55 \mathrm{~cm}^{3}$ received substrates and were subjected to vibration for compression. Then the substrate of $0.02 \mathrm{~m}$ upper layer was 
removed. For inoculated treatments, alginate beads with mycelium were applied on the substrate according to the pre-established rates, and then the tubes were filled. Because the compression, the complete amount of substrate was approximately $77 \mathrm{~cm}^{3}$ substrate $(13,000$ tubes were filled up with $1.0 \mathrm{~m}^{3}$ substrate). Thus, each rooted cutting was fertilized with $36 \mathrm{mg} \mathrm{P}$ for the commercial treatment and $18 \mathrm{mg} \mathrm{P}$ in the inoculated treatments, in which fertilization in the substrates was reduced by $50 \%$.

Subsequently, 0.06 to $0.08 \mathrm{~m}$ eucalypt minicuttings with two pairs of leaves were planted and immediately placed in a greenhouse and kept under intermittent mist irrigation, where they remained for 30 days. After 15 days under greenhouse conditions, the cuttings were fertirrigated by a hand sprinkler at seven-day intervals with $2 \mathrm{~L}$ $\mathrm{m}^{-2}$ fertilizer growing solution composed of 0.75 $\mathrm{g} \mathrm{L}^{-1}$ calcium nitrate with $19 \% \mathrm{Ca}$ and $15 \% \mathrm{~N}$; $0.9 \mathrm{~g} \mathrm{~L}^{-1} \mathrm{~N} 6-\mathrm{P} 12-\mathrm{K} 36$ Kristalon $^{\circledR} ; 2.5 \mathrm{~g} \mathrm{~L}^{-1}$ ammonium sulfate - $20 \% \mathrm{~N} ; 25 \mathrm{mg} \mathrm{L}^{-1}$ Ferrilene $^{\circledR}$ - $6 \%$; $8.5 \mathrm{mg}$ $\mathrm{L}^{-1}$ boric acid - $17 \% \mathrm{~B} ; 1.2 \mathrm{mg} \mathrm{L}^{-1}$ copper sulfate - $35 \% \mathrm{Cu} ; 0.7 \mathrm{mg} \mathrm{L}^{-1}$ zinc sulfate heptahydrate - 20 $\% \mathrm{Zn} ; 0.2 \mathrm{mg} \mathrm{L}^{-1}$ sodium molybdate - $39 \% \mathrm{Mo}$; and $6.5 \mathrm{mg} \mathrm{L}^{-1}$ manganese sulfate - $30 \% \mathrm{Mn}$. After this period, saplings underwent an acclimatization stage, in which they remained for 10 days under shade and, up to 68 days, receiving two weekly fertirrigations with two manual waterings of $2 \mathrm{~L} \mathrm{~m}^{-2}$ of solution fertilizer growing solution as described above. Subsequently, they received three fertirrigations in one week with a hardening fertilizer solution composed of $0.375 \mathrm{~g} \mathrm{~L}^{-1}$ calcium nitrate $19 \% \mathrm{Ca}$ and $15 \% \mathrm{~N} ; 0.45 \mathrm{~g} \mathrm{~L}^{-1}$ N6-P12-K36 Kristalon ${ }^{\circledR}$; $1 \mathrm{~g} \mathrm{~L}^{-1}$ potassium chloride $-62 \% \mathrm{~K} ; 25 \mathrm{mg} \mathrm{L}^{-1}$ Ferrilene $^{\circledR}-6 \%$; $8.5 \mathrm{mg} \mathrm{L}{ }^{-1}$ boric acid - $17 \% \mathrm{~B}$; $1.2 \mathrm{mg} \mathrm{L}^{-1}$ copper sulfate - $35 \% \mathrm{Cu} ; 0.7 \mathrm{mg} \mathrm{L}^{-1}$ zinc sulfate heptahydrate - $20 \% \mathrm{Zn} ; 0.2 \mathrm{mg} \mathrm{L}^{-1}$ sodium molybdate - $39 \% \mathrm{Mo}$; and $6.5 \mathrm{mg} \mathrm{L}^{-1}$ manganese sulphate - $30 \% \mathrm{Mn}$.

Considering that all growth (12 applications) and hardening (3 applications) solutions applied within the tube upper area (27-mm inner diameter) infiltrated, fertirrigations provided $0.7 \mathrm{mg} \mathrm{P}$ per sapling. In addition, cuttings did not receive any phytosanitary treatment.

\section{Sampling and evaluations}

Sapling shoot height (SH) and root collar diameter (CD) were evaluated at 90 days; after that, they were cut close to upper edge of the tube separating shoots from roots. Roots were washed under tap water to remove substrate; then, composite root samples of each plot were obtained, cut into lengths of approximately $0.02 \mathrm{~m}$, and stored in formaldehyde-acetone-ethanol at 9:1:1 (v:v:v) ratio for later evaluation of ectomycorrhizal colonization (Giovanetti and Mosse 1980). The remaining roots and shoots were dried to constant weight in a forced-air oven at $65^{\circ} \mathrm{C}$ for measurement of shoot dry matter (SDM) and root dry matter (RDM). From these data, the Dickson Quality Index (DQI) (Dickson et al., 1960) was determined through the formula: $\mathrm{DQI}=(\mathrm{SDM} / \mathrm{RDM}) /[(\mathrm{SH} / \mathrm{CD})+(\mathrm{SDM} / \mathrm{RDM})]$.

After weighing SDM, leaves were detached and weighed to determine leaf dry matter (LDM). Then they were ground in a Willey type mill and digested in nitric-perchloric acid at a 2:1 (v:v) ratio. After that, $\mathrm{P}$ concentration was determined by colorimetry and $\mathrm{K}$ concentration by photometry (Malavolta et al., 1997). In addition, $\mathrm{N}$ concentration was determined by the Kjeldahl method (distillation) after sulfuric digestion. Therefore, leaf N, P, and K contents were calculated based on the leaf dry matter (LDM) of each plant.

\section{Statistics}

Shoot height, root collar diameter, and colonized root length percentage data were transformed using $\ln (\mathrm{x}+2)$ since they did not follow normal distribution and, or, were lower than $30 \%$. In the factorial, mean values were compared by the Tukey test $(p<0.05)$ only when the fungal effect was observed. When the fungus $\times$ application rate interaction was significant, regression was performed. For comparison between each inoculated treatment (with substrate fertilization reduction) and the commercial treatment (without substrate fertilization reduction) the Dunnett test $(p<0.05)$ was used. Correlation analyses were performed among all variables, considering a $5 \%$ level of probability by the " $\mathrm{t}$ " test as significant.

\section{RESULTS}

\section{Inoculation effect}

In plants grown under $50 \%$ of fertilizer, the $\mathrm{CD}$, SH, SDM, and EMF colonization was influenced by the inoculum rate and not by the fungal species (Table 1, Figure 1). In contrast, RDM was influenced by the fungal species and not by the application rate (Tables 1 and 2). The highest RDM was observed for $S$. areolatum (464 mg per cutting) inoculated plants, which were 1.3 times higher than $P$. microcarpus inoculated ones (368 mg per cutting). DQI was not affected either by the type of fungi or by inoculum application rates (Tables 1 and 2).

Root collar diameter and $\mathrm{SH}$ showed linear behavior with increasing inoculum application rates, reaching $2.78 \mathrm{~mm}$ for $\mathrm{CD}$ and $0.25 \mathrm{~m}$ for SH (Figures 1a, 1b) at the highest rate (15 beads). At this rate, CD was 1.1 times higher than for non-inoculated plants (Figure 1a), and $\mathrm{SH}$ was 1.2 times higher (Figure 1b). Although the SDM had been influenced by the inoculum application 
Table 1. Summary of ANOVA table for all variables analyzed

\begin{tabular}{|c|c|c|c|c|c|c|}
\hline Variable & Rate (R) & Fungi (F) & $\mathbf{R} \times \mathbf{F}$ & Commercial $\times$ factorial design & $\mathrm{CV}$ & MSR \\
\hline & & & & & $\%$ & \\
\hline Collar diameter & $* *$ & $\mathrm{~ns}$ & $\mathrm{~ns}$ & $* *$ & 2.58 & 0.0016 \\
\hline Shoot height & $* *$ & $\mathrm{~ns}$ & $\mathrm{~ns}$ & $* *$ & 1.75 & 0.0032 \\
\hline Shoot dry matter & * & $\mathrm{ns}$ & $\mathrm{ns}$ & $* *$ & 15.93 & $17,475.66$ \\
\hline Root dry matter & $\mathrm{ns}$ & $* *$ & $\mathrm{~ns}$ & $* *$ & 17.66 & $5,895.76$ \\
\hline Colonized root length & $* *$ & $\mathrm{~ns}$ & $\mathrm{~ns}$ & $* *$ & 14.68 & 0.0978 \\
\hline Dickson Quality Index & $\mathrm{ns}$ & $\mathrm{ns}$ & $\mathrm{ns}$ & $\mathrm{ns}$ & 27.35 & 0.0001 \\
\hline P leaf concentration & $* *$ & $* *$ & $* *$ & $* *$ & 8.54 & 0.0058 \\
\hline $\mathrm{P}$ leaf content & $* *$ & $*$ & $* *$ & $\mathrm{~ns}$ & 29.41 & 0.0172 \\
\hline $\mathrm{N}$ leaf concentration & $* *$ & $\mathrm{~ns}$ & $\mathrm{~ns}$ & $\mathrm{~ns}$ & 20.63 & 11.0877 \\
\hline $\mathrm{N}$ leaf content & $* *$ & $\mathrm{~ns}$ & $\mathrm{~ns}$ & $* *$ & 34.43 & 8.1055 \\
\hline $\mathrm{K}$ leaf concentration & $* *$ & $\mathrm{~ns}$ & $\mathrm{~ns}$ & $*$ & 14.97 & 12.5376 \\
\hline $\mathrm{K}$ leaf content & $* *$ & $\mathrm{~ns}$ & $\mathrm{~ns}$ & $* *$ & 24.98 & 9.2611 \\
\hline
\end{tabular}

ns: not significant; * and **: significant at 5 and $1 \%$ by the "F" test, respectively. CV: coefficient of variation; MSR: mean square of residuals.

Table 2. Root dry matter and Dickson Quality Index for Eucalyptus urophylla rooted cuttings that received increasing inoculum rates of Amanita muscaria, Elaphomyces anthracinus, Pisolithus microcarpus, and Scleroderma areolatum and grown for 90 days in a commercial nursery

\begin{tabular}{|c|c|c|c|c|c|c|}
\hline \multirow{2}{*}{ Fungus } & \multirow{2}{*}{ Commercial $^{(1)}$} & \multicolumn{4}{|c|}{ Calcium alginate beads with mycelium per mini-cutting } & \multirow{2}{*}{ Mean } \\
\hline & & $\mathbf{0}$ & $\mathbf{5}$ & 10 & 15 & \\
\hline & \multicolumn{6}{|c|}{ Root dry mass (mg per plant) } \\
\hline A. muscaria & & $410^{*}$ & $401^{*}$ & $368^{*}$ & $448^{*}$ & $407 \mathrm{AB}$ \\
\hline E. anthracinus & & $435^{*}$ & $375^{*}$ & $439^{*}$ & $437^{*}$ & $422 \mathrm{AB}$ \\
\hline P. microcarpus & & $381^{*}$ & $377^{*}$ & $342^{*}$ & $373^{*}$ & $368 \mathrm{~B}$ \\
\hline S. areolatum & & $486^{*}$ & $522^{*}$ & $403^{*}$ & $445^{*}$ & $464 \mathrm{~A}$ \\
\hline \multirow[t]{2}{*}{ Mean } & 747 & 428 & $419^{*}$ & 388 & 426 & 415 \\
\hline & \multicolumn{6}{|c|}{ Dickson Quality Index } \\
\hline A. muscaria & & $0.03^{*}$ & $0.04^{*}$ & $0.03^{*}$ & $0.05^{*}$ & 0.04 \\
\hline E. anthracinus & & $0.04^{*}$ & $0.04^{*}$ & $0.04^{*}$ & $0.05^{*}$ & 0.04 \\
\hline P. microcarpus & & $0.04^{*}$ & $0.04^{*}$ & $0.03^{*}$ & $0.03^{*}$ & 0.04 \\
\hline S. areolatum & & $0.04^{*}$ & $0.05^{*}$ & $0.03^{*}$ & $0.05^{*}$ & 0.04 \\
\hline Mean & 0.11 & 0.04 & $0.04^{*}$ & 0.03 & 0.04 & 0.04 \\
\hline
\end{tabular}

rate (Table 1), no regression equation could be fitted (Figure 1c). Plants inoculated with 15 beads had higher SDM (862 mg per plant), 1.2 times higher than non-inoculated plants (733 mg per plant). Colonized root length percentage increased together with application rates for all fungi in a similar manner, showing quadratic behavior; and the largest colonization (16\%) was found at the highest rate (Figure 1d). The non-inoculated plants grown in substrate with $50 \%$ fertilization reduction had an average of $1 \%$ colonization.

Leaf $\mathrm{P}$ concentration and content were influenced by inoculum application rates and fungal species interaction (Table 1, Figures 2a, 2b). Among the
EMF evaluated, only $P$. microcarpus did not increase plant $\mathrm{P}$ concentration and content at increasing inoculum application rates. For the others, leaf $\mathrm{P}$ concentration and content increased up to 10 beads per mini-cutting. However, regression equations were fitted solely for leaf $\mathrm{P}$ concentration and contents in plants inoculated with $A$. muscaria and contents in plants inoculated with $S$. aerolatum (Figures 2a, 2b). In such cases, there is quadratic behavior with mean values double those of non-inoculated plants. Although no regression equation was fitted, the highest $\mathrm{P}$ concentrations were observed for $S$. aerolatum inoculated plants (2.2 times higher than non-inoculated ones) and 

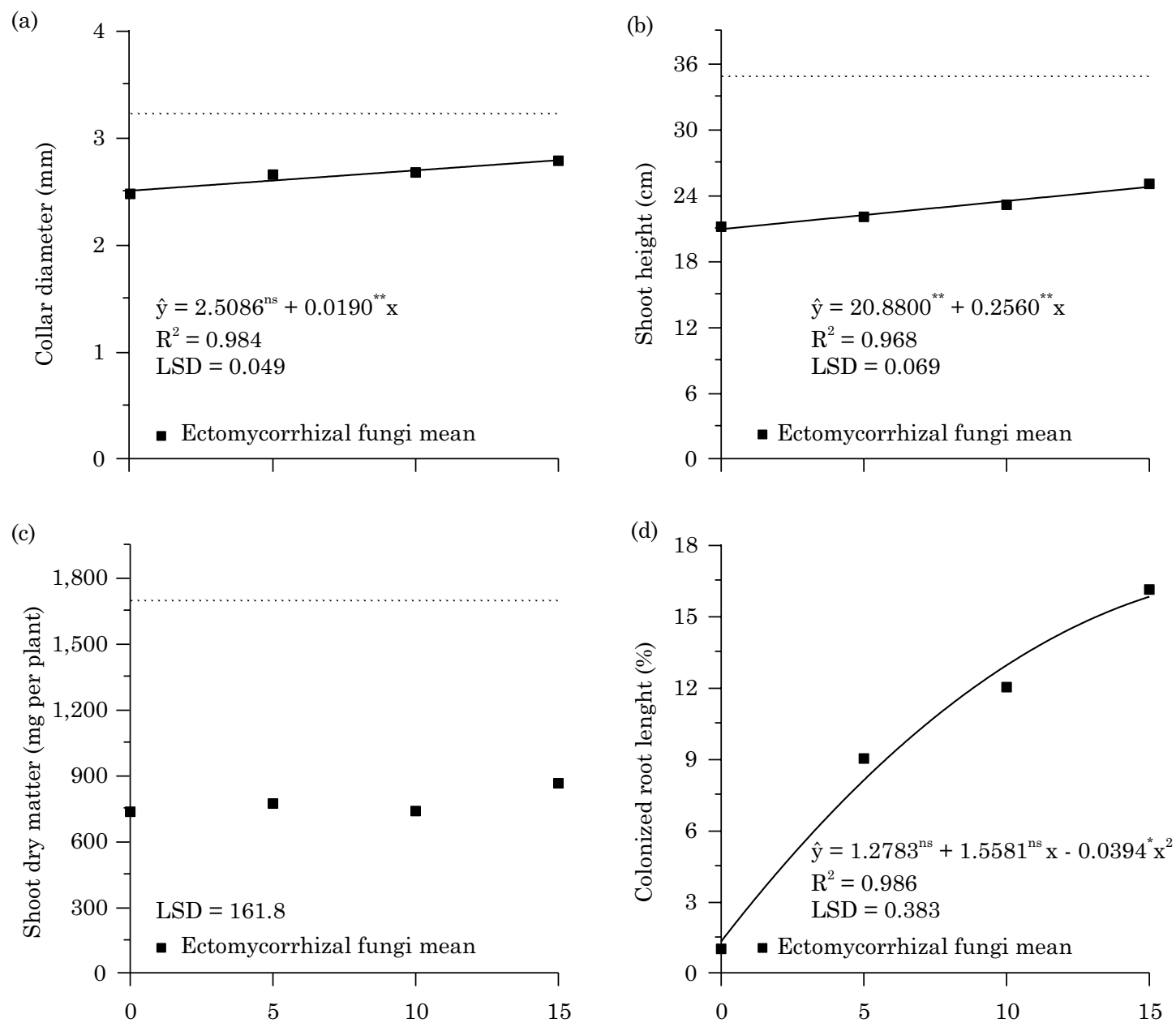

Ectomycorrhizal fungi inoculum, calcium alginate beads with mycelium per mini-cutting

Figure 1. Collar diameter (a), shoot height (b), shoot dry matter (c) and colonized root length (d) of Eucalyptus urophylla rooted cuttings that received increasing inoculum application rates of Amanita muscaria, Elaphomyces anthracinus, Pisolithus microcarpus, and Scleroderma areolatum and grown for 90 days in a commercial nursery. Dash-dot line shows results for non-inoculated rooted cuttings without substrate fertilization reduction (commercial). Since the commercial sapling was not colonized, the dotted line is absent in (d). * and **: significant at, respectively, 5 and $1 \%$ by the "t" test; ${ }^{\text {ns: }}$ not significant. LSD: least significant difference.

the highest contents were observed for plants inoculated with $E$. anthracinus (2.0 times higher than non-inoculated ones), both cases at the 10 bead per mini-cutting application rate.

Both leaf concentration and $\mathrm{N}$ and $\mathrm{K}$ content were influenced by inoculum application rates and not by the fungal species (Table 1, Figures 2c, 2d, $2 \mathrm{e}, 2 \mathrm{f})$. Leaf $\mathrm{N}$ and $\mathrm{K}$ concentration and content increased quadratically with inoculum application rates (Figures 2c, 2d, 2e, 2f). The highest $\mathrm{N}$ concentrations were observed in plants receiving the rate of 14 beads with inoculum $\left(18.9 \mathrm{~g} \mathrm{~kg}^{-1}\right)$, 1.6 times higher than non-inoculated plants $\left(12.0 \mathrm{~g} \mathrm{~kg}^{-1}\right)$ (Figure 2c). Leaf $\mathrm{N}$ content was higher in plants supplied with 13 beads (13.7 $\mathrm{mg}$ per plant), which was 2.4 times higher than in non-inoculated plants (5.39 mg per plant) (Figure 2d). Regarding $\mathrm{K}$, larger concentrations $\left(27.1 \mathrm{~g} \mathrm{~kg}^{-1}\right)$ were observed in plants treated with 11 beads, which were on average 1.6 times higher than concentrations in non-inoculated plants (16.9 $\mathrm{g} \mathrm{kg}^{-1}$ ) (Figure 2e). In addition, the highest leaf $\mathrm{K}$ contents were found for saplings with 15 beads (9.9 mg per plant), $30 \%$ times higher than contents for non-inoculated ones (7.6 mg per plant) (Figure 2f).

Colonization did not correlate with the CD, SH, SDM and RDM, but was positively correlated with the contents of all nutrients evaluated (Table 3). However, only $\mathrm{K}$ contents correlated with $\mathrm{SH}$ and SDM. 
(a)

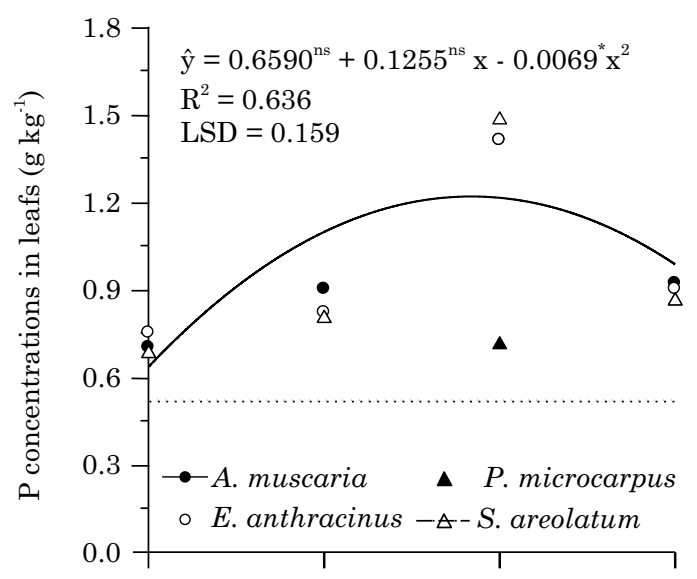

(c)

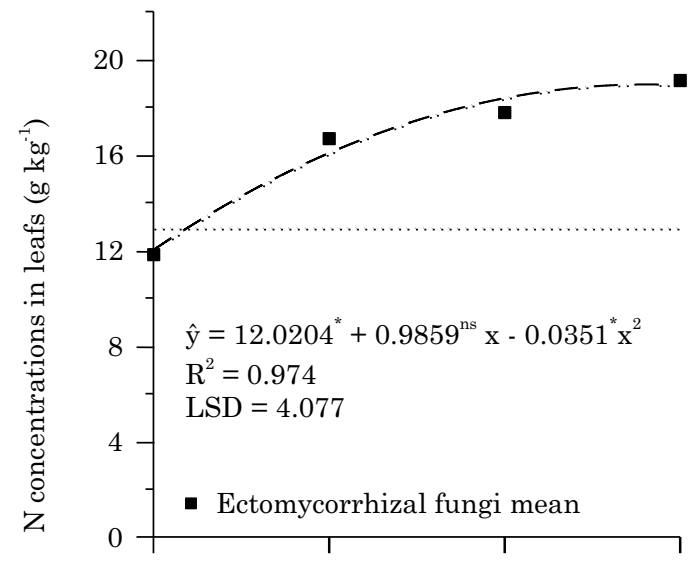

(e)

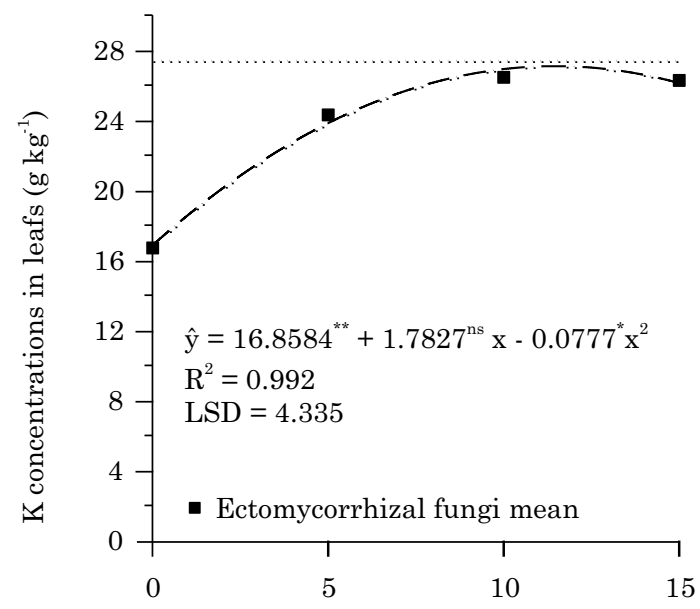

(b)

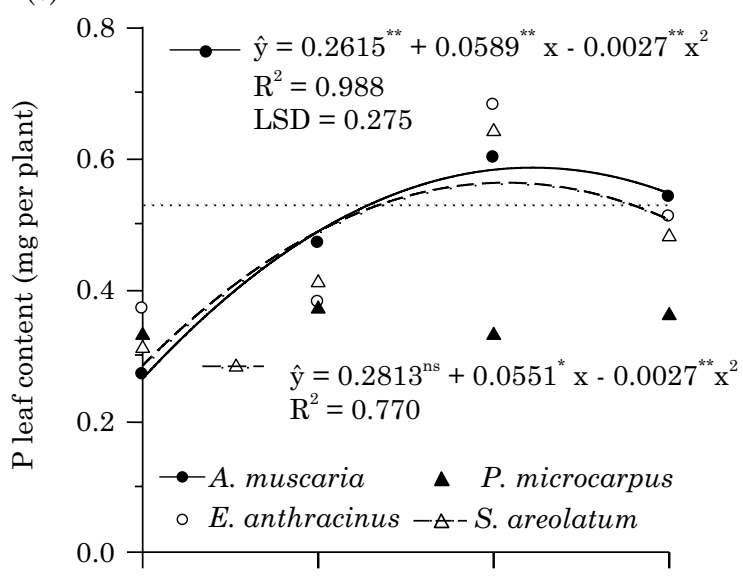

(d)

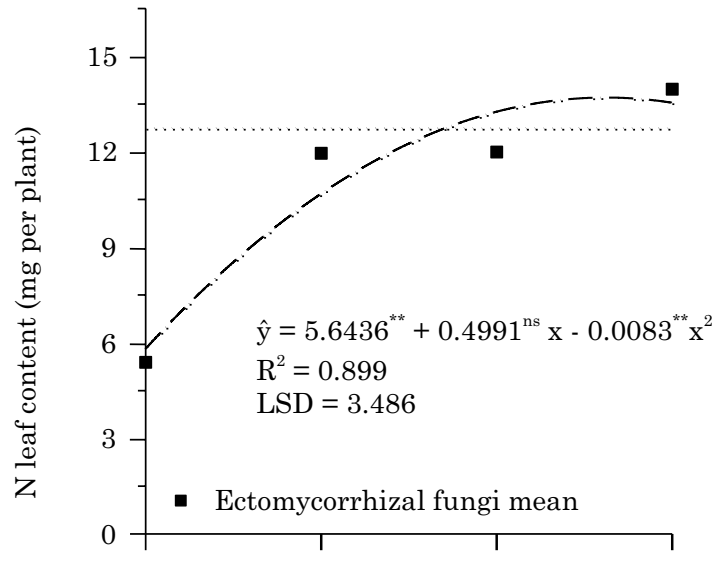

(f)

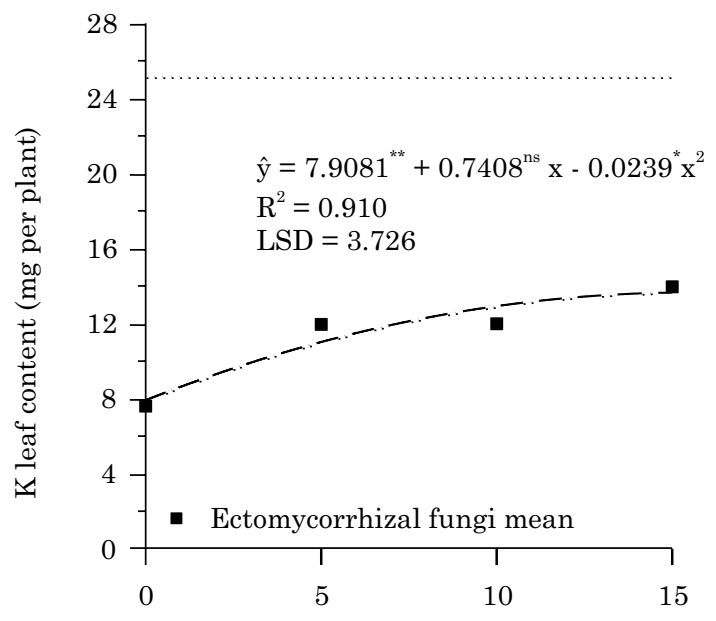

Ectomycorrhizal fungi inoculum, calcium alginate beads with mycelium per mini-cutting

Figure 2. Leaf concentrations and contents of $\mathrm{P}(\mathrm{a}, \mathrm{b}), \mathrm{N}(\mathrm{c}, \mathrm{d})$, and $\mathrm{K}(\mathrm{e}, \mathrm{f})$ for Eucalyptus urophylla rooted cuttings that received increasing inoculum application rates of Amanita muscaria, Elaphomyces anthracinus, Pisolithus microcarpus, and Scleroderma areolatum and grown for 90 days in a commercial nursery. Dash-dot line shows results for non-inoculated rooted cuttings without substrate fertilization reduction (commercial). * and **: significant at, respectively, 5 and $1 \%$ by the " $t$ " test; ns: not significant. LSD: least significant difference. 
Table 3. Correlation matrix between collar diameter, shoot height, shoot dry matter, root dry matter, Dickson Quality Index, colonized root length, and leaf concentrations and contents of $P, N$, and $K$ for Eucalyptus urophylla rooted cuttings that received increasing inoculum application rates of Amanita muscaria, Elaphomyces anthracinus, Pisolithus microcarpus, and Scleroderma areolatum and grown for 90 days in a commercial nursery

\begin{tabular}{|c|c|c|c|c|c|c|c|c|c|c|c|}
\hline Variable & $\begin{array}{c}\text { Collar } \\
\text { diameter }\end{array}$ & $\begin{array}{l}\text { Shoot } \\
\text { height }\end{array}$ & $\begin{array}{l}\text { Shoot } \\
\text { dry } \\
\text { matter }\end{array}$ & $\begin{array}{c}\text { Root } \\
\text { dry } \\
\text { matter }\end{array}$ & $\begin{array}{c}\text { Dickson } \\
\text { Quality } \\
\text { Index }\end{array}$ & $\begin{array}{c}\text { Colonized } \\
\text { root } \\
\text { length }\end{array}$ & $\begin{array}{c}\text { P leaf } \\
\text { concentration }\end{array}$ & $\begin{array}{c}\text { P leaf } \\
\text { content }\end{array}$ & $\begin{array}{c}\text { N leaf } \\
\text { concentration }\end{array}$ & $\begin{array}{c}\text { N leaf } \\
\text { content }\end{array}$ & $\begin{array}{c}\text { K leaf } \\
\text { concentration }\end{array}$ \\
\hline Shoot height & $0.638^{* *}$ & & & & & & & & & & \\
\hline $\begin{array}{l}\text { Shoot dry } \\
\text { matter }\end{array}$ & $0.608^{* *}$ & $0.794^{* *}$ & & & & & & & & & \\
\hline $\begin{array}{l}\text { Root dry } \\
\text { matter }\end{array}$ & $0.286^{*}$ & $0.563^{* *}$ & $0.681^{* *}$ & & & & & & & & \\
\hline $\begin{array}{l}\text { Dickson } \\
\text { Quality Index }\end{array}$ & $0.489 * *$ & $0.659 * *$ & $0.963^{* *}$ & $0.771^{* *}$ & & & & & & & \\
\hline $\begin{array}{l}\text { Colonized root } \\
\text { length }\end{array}$ & $0.139^{\mathrm{ns}}$ & $0.070^{\mathrm{ns}}$ & $-0.104^{\mathrm{ns}}$ & $-0.235^{\mathrm{ns}}$ & $-0.214^{\mathrm{ns}}$ & & & & & & \\
\hline $\begin{array}{l}\text { P leaf } \\
\text { concentration }\end{array}$ & $-0.009^{\mathrm{ns}}$ & $-0.182^{\mathrm{ns}}$ & $-0.296^{\mathrm{ns}}$ & $-0.266^{\mathrm{ns}}$ & $-0.329^{\mathrm{ns}}$ & $0.401^{* *}$ & & & & & \\
\hline $\mathrm{P}$ leaf content & $0.336^{* *}$ & $0.165^{\mathrm{ns}}$ & $0.390 * *$ & $0.101^{\mathrm{ns}}$ & $0.352^{* *}$ & $0.361^{* *}$ & $0.616^{* *}$ & & & & \\
\hline $\begin{array}{l}\text { N leaf } \\
\text { concentration }\end{array}$ & $0.098^{\mathrm{ns}}$ & $0.025^{\mathrm{ns}}$ & $-0.063^{\mathrm{ns}}$ & $-0.250^{\mathrm{ns}}$ & $-0.132^{\mathrm{ns}}$ & $0.570 * *$ & $0.282^{*}$ & $0.286^{*}$ & & & \\
\hline $\mathrm{N}$ leaf content & $0.393^{* *}$ & $0.406^{* *}$ & $0.611^{* *}$ & $0.253^{*}$ & $0.566^{* *}$ & $0.328^{* *}$ & $-0.013^{\mathrm{ns}}$ & $0.591^{* *}$ & $0.660^{* *}$ & & \\
\hline $\begin{array}{l}\text { K leaf } \\
\text { concentration }\end{array}$ & $0.238^{\mathrm{ns}}$ & $0.347^{* *}$ & $0.142^{* *}$ & $0.030^{\mathrm{ns}}$ & $0.035^{\mathrm{ns}}$ & $0.441^{* *}$ & $0.382^{* *}$ & $0.375^{* *}$ & $0.453^{* *}$ & $0.343^{* *}$ & \\
\hline K leaf content & $0.516^{* *}$ & $0.656^{* *}$ & $0.808^{* *}$ & $0.485^{* *}$ & $0.742^{* *}$ & $0.163^{\mathrm{ns}}$ & $-0.034^{\mathrm{ns}}$ & $0.615^{* *}$ & $0.233^{\mathrm{ns}}$ & $0.768^{* *}$ & $0.599 * *$ \\
\hline
\end{tabular}

* and ${ }^{* *}$ : significant at, respectively, 5 and $1 \%$ by the "t" test; ${ }^{\text {ns: }}$ not significant.

\section{Effect of substrate fertilization reduction}

Plants fertilized at a level of $50 \%$ and inoculated with EMF showed a smaller CD, $\mathrm{SH}, \mathrm{SDM}, \mathrm{RDM}$, and DQI than the commercial treatment (non-inoculated and $100 \%$ fertilization) (Table 2, Figure 1). Commercial plants had no ectomycorrhizal colonization (Figure 1d). Those non-inoculated, but grown with $50 \%$ reduction in fertilizers showed $1 \%$ of their root length colonized by EMF.

Root dry matter was 1.5 times and DQI was 2.7 times higher for commercial plants than those grown under $50 \%$ fertilization reduction (Table 2 ). For plants under fertilization reduction, the DQI index classified the non-inoculated plants as equal to those that had the highest rate of inoculum (Table 2). Despite reducing fertilization by half, leaf $\mathrm{P}, \mathrm{N}$, and $\mathrm{K}$ concentrations and contents for inoculated saplings with the highest inoculum rates were greater than or equal to the commercial ones (Figures 2a, 2b, 2c, 2d, 2e), except for leaf K content (Figure 2f). Plants inoculated with 10 beads of $S$. areolatum inoculum had a leaf $\mathrm{P}$ concentration (1.48 $\left.\mathrm{g} \mathrm{kg}^{-1}\right) 2.8$ times higher than commercial plants $\left(0.53 \mathrm{~g} \mathrm{~kg}^{-1}\right)$ (Figure 2a). Rooted cuttings inoculated with 15 beads had an $\mathrm{N}$ concentration $\left(19.1 \mathrm{~g} \mathrm{~kg}^{-1}\right) 1.5$ times greater than the commercial cuttings (12.9 $\mathrm{g} \mathrm{kg}^{-1}$ ) (Figure $2 \mathrm{c}$ ).

\section{DISCUSSION}

\section{Inoculation effect}

Inoculation with the highest EMF application rate in eucalypt mini-cuttings in a commercial nursery promoted growth, ectomycorrhizal symbiosis, and improved nutrient uptake. Ectomycorrhizal fungi species differed in their capacity to increase leaf $\mathrm{P}$ concentration and content (Figures 2a, 2b); however, they did not differ in terms of growth promotion (Figures 1a, 1b, 1c) and root colonization ability (Figure 1d), and they also raised leaf $\mathrm{K}$ and $\mathrm{N}$ concentration and content (Figures 2c, 2d, 2e, 2f). This similar behavior among EMF species observed in growth promotion, root colonization, and plant nutrition for some nutrients differs from most studies found in the literature (Alves et al., 2001; Silva et al., 2003; Souza et al., 2004, 2008; Chen et al., 2006c).

The increase in eucalypt $\mathrm{CD}, \mathrm{SH}$, and SDM promoted by inoculation with increasing application rates of different EMF species (Figures 1a, 1b, 1c) was also observed by other authors in eucalypt seedlings (Alves et al., 2001; Souza et al., 2004, 2008). E. dunnii seedlings had greater CD (1.4 times), SH (1.3 times), and SDM (1.7 times) levels when inoculated with Pisolithus sp. (UFSC-Pt24) 
isolate compared to non-inoculated plants (Alves et al., 2001); and they had greater SDM when inoculated with Scleroderma sp. (UFSC-Sc68) isolate (3.3 times) (Souza et al., 2008), with $P$. microcarpus (UFSC-Pt116) isolate (1.2 times), and with C. angustisporus (UFSC-Ch163) isolate (1.3 times) (Souza et al., 2004). These results are greater than or equal to the CD and SDM observed in this study, which were 1.1 and 1.2 times higher respectively, always at the highest application rate without reaching a maximum (Figures 1a, 1b, 1c). In contrast, the growth of rooted cuttings did not correlate with colonization (Table 2).

Major growth observed at the highest application rate (Figures 1a, 1b, 1c) differs from results of other studies. In $E$. dunnii seedlings inoculated with Pisolithus sp. (UFSC-pT24) and cultivated for 100 days, the largest CD $(2.5 \mathrm{~mm})$ and $\mathrm{SH}(26.2 \mathrm{~cm})$ were observed in seedlings that received $3 \%$ inoculum produced in a mixture of a vermiculite-peat culture medium (Alves et al., 2001). This difference may be due to different types of inocula used in this study. Another explanation may be that in this study a possible effect of the association with arbuscular mycorrhiza fungi that could be present together with ECM fungi in the initial growth of eucalyputs saplings was not considered.

The ideal inoculant application rate depends on the goals of the study. If the expected benefit of ectomycorrhizal fungi is after transplanting, by increasing the survival and growth of plants in the field, the rate that would provide greatest root colonization should be used, even if it did not result in increased growth under nursery conditions. This should occur without preventing the saplings from reaching the standard considered ideal for transplanting in the same growing period. However, if the expected benefit is greater rooting of promising clones, the most extensive colonization could undermine the rooting process rather than promote it.

Low colonization in the control (non-inoculated with $50 \%$ fertilization) (Figure 1d) may have been because the substrate for rooted cuttings was composed of vermiculite, carbonized rice husk, and coconut fiber, that is, only inert materials. Ectomycorrhizae presence in the control may be due to spores brought by irrigation water or wind-borne spores, since the nursery is located near a eucalypt plantation. Notably, in this study, the substrate for rooted cuttings was not sterilized and the irrigation water was not distilled, unlike other studies with EMF (Alves et al., 2001; Souza et al., 2004). This shows that by using suitable rates of $P$ for colonization, sapling production conditions used in the forestry sector may allow the introduction of selected fungal isolates.

The increase in colonization rate observed in inoculated rooted cuttings from increasing application rates (Figure 1d) was also observed in E. dunnii seedlings that received Pisolithus sp. inoculum produced in a vermiculite-peatculture medium (Alves et al., 2001). Root length colonization of $16 \%$, observed at the highest application rate of inoculum (15 beads), was higher than the highest percentage observed in E. dunnii inoculated by 10 species and, or, EMF isolates (Souza et al., 2008). However, it was lower than that reported in eucalypt by other authors (Alves et al., 2001; Chen et al., 2006c). Nevertheless, as mentioned earlier, all these studies had lower $\mathrm{P}$ fertilization application rates.

The similar behavior among fungal species in promoting plant growth and root colonization and the lower intensity of inoculation benefits on growth characteristics (Figure 1) compared to the literature may be due to the different type of inocula and different experimental conditions. Furthermore, the interaction between symbionts may have been poor because the fungi tested were obtained from various species of eucalypt and other genera, also from different regions. This demonstrates the need for selection of specific isolates. The aforementioned studies differ from the current study because they did not use clonal saplings and were developed under greenhouse conditions with sterilized substrates, low P fertilization, higher plant growth time (100 and 120 days), and inoculum production in a vermiculite-peat-culture medium mixture. In these studies, the amount of $\mathrm{P}$ for seedlings ranged from $0.25 \mathrm{mg}$ using $\mathrm{Ca}\left(\mathrm{H}_{2} \mathrm{PO}_{4}\right)_{2} \cdot \mathrm{H}_{2} \mathrm{O}$ (Souza et al., 2004) to $8.7 \mathrm{mg}$ using $14 \mathrm{~N}-8 \mathrm{P}-8 \mathrm{~K}$ slow-release fertilizer $\left(\right.$ Nutricote $^{\circledR}$ ) (Alves et al., 2001), that is, up to two times lower than the $18 \mathrm{mg} \mathrm{P}$ for rooted cuttings provided in the MAP source $\left(60.8 \% \mathrm{P}_{2} \mathrm{O}_{5}\right)$ plus slow-release fertilizer $19 \mathrm{~N}-6 \mathrm{P}-10 \mathrm{~K}$ (Osmocote ${ }^{\circledR}$ ) used in this study, without considering the weekly fertirrigation with $P$.

Despite the fact of greater ectomycorrhizal colonization (16 times) and nutrient uptake in inoculated plants, they and the control plants grown under fertilization reduction had the same DQI values (Table 2), which may be due to the fact that this index does not consider those characteristics.

The increase in inoculated plant $\mathrm{P}$ content for three out of four EMFs used, according to inoculum application rates and their differential ability in promoting $\mathrm{P}$ uptake (Figures $2 \mathrm{a}, 2 \mathrm{~b}$ ) corroborates with some results reported in the literature (Alves et al., 2001; Chen et al., 2006b; Souza et al., 2008). E. dunnii seedlings inoculated with $P$. microcarpus (UFSC-Pt188) accumulated nine times more $\mathrm{P}(528 \mu \mathrm{g}$ per plant) than non-inoculated seedlings (60 $\mu \mathrm{g}$ per plant) (Souza et al., 2008). For $E$. urophylla seedlings inoculated with six species or isolates of Scleroderma, the increase was up to 1.8 times (Chen et al., 2006b). Evaluating seven application rates of $\mathrm{P}$ for maximum efficiency 
of mycorrhizal association between seedlings of Eucalyptus grandis and Pisolithus tinctorius (Pt 854) grown in $2.0 \mathrm{dm}^{3}$ of soil, Vieira and Peres (1988) observed increased $\mathrm{P}$ content only up to $23 \mathrm{mg} \mathrm{kg}^{-1} \mathrm{P}$ (third rate), in which inoculated plants stocked 5.1 times more $\mathrm{P}$ than non-inoculated ones. E. grandis seedlings inoculated with three isolates of Pisolithus sp. increased P content from 1.3 to 2.0 times compared to non-inoculated ones (Andreazza et al., 2004). Thus, it can be noted that the current study, despite the high $\mathrm{P}$ fertilization rate, the two-fold increase of $\mathrm{P}$ content in inoculated seedlings over the control was similar to results from two out of four outcomes listed above. Moreover, in the present study, EMF inoculation also increased leaf $\mathrm{P}$ concentration (2.2 times), indicating that the increased production of SDM in inoculated plants was not sufficient to lead to a dilution effect on $\mathrm{P}$ and showing that three out of four EMF were able to promote better $\mathrm{P}$ nutritional status and "luxury" uptake. These observations are confirmed by the correlation between colonization and $\mathrm{P}$ concentrations, and also the absence of correlation between $\mathrm{P}$ concentration and growth (Table 3). These increased $\mathrm{P}$ concentrations can enhance plant growth after transplanting in the field compared to non-inoculated plants (Chen et al., 2006a). Usually, in the literature, for data on EMF inoculation in eucalypt, nutrient levels are usually not shown, probably due to the absence of an inoculation effect on this variable.

Just as for $\mathrm{P}$ concentration, there are few studies on the effect of EMF inoculation on $\mathrm{N}$ and $\mathrm{K}$ concentration and content in forest species. This may also be due to lack of observation of inoculation effects on these variables, because it is known that the greatest EMF benefit is on the uptake of low-mobility elements in the soil, such as P. Studies on eucalypt showing results from these variables are even rarer. In $E$. grandis saplings inoculated with the $\mathrm{Pt} 854$ isolate of $P$. tinctorius, which received growing application rates of $\mathrm{P}$, increases of 3.3 times for $\mathrm{N}$ content and 2.6 times for $\mathrm{K}$ were observed when compared to non-inoculated plants at the rate of $23 \mathrm{mg} \mathrm{kg}^{-1} \mathrm{P}$ (Vieira and Peres, 1988). In $E$. grandis seedlings inoculated with eight fungal treatments (four Pisolithus sp. isolates or mixtures thereof), increases in $\mathrm{N}$ content were observed for seven treatments and increases in $\mathrm{K}$ content for three, with the largest increases in $\mathrm{N}$ of 2.3 times and $\mathrm{K}$ of 1.9 times compared to the control (non-inoculated) (Silva et al., 2003). In E. urophylla seedlings inoculated with spores of six species or isolates of Scleroderma, increases of up to 2.2 times in $\mathrm{N}$ content and up to 1.7 times in $\mathrm{K}$ content was observed for seedling shoots (Chen et al., 2006b). In general, the rises in $\mathrm{N}$ and $\mathrm{K}$ content shown above are the best results of the species and/or isolates evaluated. In some cases they were higher and in others lower than the increase in $\mathrm{N}$ (1.6 times) and $\mathrm{K}$ (1.8 times) content observed in this study (Figures 2d, 2f). In addition, unlike the present study, the effect of inoculation on these nutrients was influenced by the species and isolate. Once again, it is important to remember that fertilization rates in the present study, although reduced by $50 \%$, were much larger than those reported in the literature, and this may have influenced both the effective response and lack of variation of the results among species. The studies mentioned above do not show any results on $\mathrm{N}, \mathrm{P}$, and $\mathrm{K}$ concentrations, which suggests that the higher nutrient contents came from increased plant growth from the EMF effect on other factors, such as water uptake, which go against the results of this study, which affirms the influence of nutrient uptake. Therefore, in addition to the increase in $\mathrm{K}$ content and concentration promoted by EMF inoculation (Figure 2), the positive correlation between $\mathrm{K}$ concentration and colonization, and the lack of correlation between all the growth characteristics and colonization (Table 3), indicates that the observed increase in growth (Figure 1), although not very expressive, was due to better $\mathrm{K}$ nutrition.

\section{Effect of substrate fertilization reduction}

Plants grown in substrate with reduced fertilization and colonized with fungi were healthy; they did not show any symptoms of nutritional deficiency and pathogen damages; clods were well-shaped; plants had more than four pairs of well-formed leaves; and SH was greater than $20 \mathrm{~cm}$, as proposed by Alfenas et al. (2004). Nevertheless, these plants were smaller than those of the commercial treatment (Table 2, Figure 1).

Ectomycorrhizal absence in commercial saplings (Figure 1d), different from that observed in control plants, might be due to the larger amount of fertilizer used. It is known that high rates of fertilizers, especially phosphates, inhibit ectomycorrhizal colonization (Soares et al., 1990; Souza et al., 2004). This result demonstrates the importance of better defining the best $P$ application rate that provides colonization able to promote benefits to the plants without the need for increasing sapling production time.

As the calculation of DQI considers $\mathrm{CD}, \mathrm{SH}$, and SDM, and these characteristics were higher for commercial plants (Figure 1), this index classified commercial plants as being more suitable for transplanting (Table 3). Nevertheless, it is reported in the literature that colonized and well-nourished plants have adaptive advantages after transplanting to the field, such as increased survival and growth (Chen et al., 2006a). In addition, as discussed above, the plants grown in the substrate with reduced fertilization were suitable for transplanting. Thus, the DQI is not adequate for evaluating the quality of EMF colonized rooted cuttings. 
The higher $\mathrm{P}, \mathrm{N}$, and $\mathrm{K}$ concentrations, and content of $\mathrm{N}$ and $\mathrm{P}$ in plants receiving the highest application rates of inoculum compared to commercial plants showed that EMF inoculation was effective in promoting enhanced nutrient supply. In addition, providing plants with mycorrhizae at the time of transplanting can help with nutritional balance under commercial nursery conditions. Inoculated plants also showed higher $\mathrm{N}$ and $\mathrm{K}$ concentrations (Figures 1c, 1e) than those considered suitable for rooted cuttings of E. grandis (N: $13-15 \mathrm{~g} \mathrm{~kg}^{-1}$; K: $15-20 \mathrm{~g} \mathrm{~kg}^{-1}$ ) at an age of 80 to 100 days (Alfenas et al., 2004). Regarding $\mathrm{P}$ concentration, although it was lower in the inoculated plants than the level adequate for rooted cuttings of eucalypt (P 1.5-2.0 $\mathrm{g} \mathrm{kg}^{-1}$ ) (Alfenas et al., 2004), the concentration observed in plants inoculated with 10 beads was 2.4 times higher than the concentration in commercial plants.

Enhanced nutrient uptake by rooted cuttings promoted by EMF compared to non-inoculated plants is unprecedented in the literature and displays the possibility of eucalypt forest establishment using previously colonized plants, within Brazilian conditions. This reinforces the need for studies to evaluate the influence of ectomycorrhizal symbiosis and the need for sapling quality indexes to consider the root ectomycorrhizal colonization rate at the time of transplanting. It is recommend that the colonized root length percentage be one of the key parameters in assessing seedling quality since it is related to plant vigor and fitness for growth and development under field conditions, increasing the chances of plant survival (Garbaye, 1990).

\section{CONCLUSIONS}

EMF inoculation promoted similar increases in growth, colonization, and $\mathrm{N}$ and $\mathrm{K}$ uptake for rooted cuttings of eucalypt grown in commercial nurseries.

The highest inoculum application rate provided increased shoot height, collar diameter, dry matter production, and fungal colonization.

Application rates near 10 beads per mini-cutting provided higher concentrations and contents of $\mathrm{P}$, $\mathrm{N}$, and $\mathrm{K}$.

Inoculation for eucalypt rooted cuttings by Amanita muscaria (UFSC-Am161), Elaphomyces anthracinus (Amance), and Scleroderma areolatum (UFSC-Sc129) increased concentrations and contents of $\mathrm{P}$ in a different manner.

The rooted cuttings colonized by ectomycorrhizal fungi have sufficient quality for transplanting at 90 days.

\section{ACKNOWLEDGMENTS}

We would like to acknowledge the Bioprocesses Laboratory of the Universidade Federal de Santa Catarina (UFSC) for providing the inoculum, the Arcelor Mittal Company for the experimental facilities, the Universidade Federal dos Vales do Jequitinhonha e Mucuri (UFVJM) for analyses of performance, and the $\mathrm{CNPq}$ and FAPEMIG for financial support.

\section{REFERENCES}

Aggangan NS, Heung KM, Sim HH. Growth response of Acacia mangium Willd. seedlings to arbuscular mycorrhizal fungi and four isolates of the ectomycorrhizal fungus Pisolithus tinctorius (Pers.) Coker and Couch. New For. 2010;39:215-30.

Alfenas AC, Zauza EAV, Mafia RG, Assis TF. Clonagem e doenças do eucalipto. Viçosa, MG: Universidade Federal de Viçosa; 2004.

Alves JR, Souza O, Podlech PAS, Giachini AJ, Oliveira VL. Efeito de inoculante ectomicorrízico produzido por fermentação semi-sólida no crescimento de Eucalyptus dunnii Maiden. Pesq Agropec Bras. 2001;36:307-13.

Andreazza R, Antoniolli ZI, Silva RF, Longhi SJ. Espécies de Pisolithus sp. na produção de mudas de Eucalyptus grandis Hill ex Maiden em solo arenoso. Ci Flor. 2004;14:51-60.

Chen YL, Dell B, Malajczuk N. Effect of Scleroderma spore density and age on mycorrhiza formation and growth of containerized Eucalyptus globulus and E. urophylla seedlings. New For. 2006a;31:453-67.

Chen YL, Kang LH, Dell B. Inoculation of Eucalyptus urophylla with spores of Scleroderma in a nursery in south China: comparison of field soil and potting mix. For Ecol Manage. 2006b;222:439-49.

Chen YL, Kang LH, Malajczuk N, Dell B. Selecting ectomycorrhizal fungi for inoculating plantations in South China: effect of Scleroderma on colonization and growth of exotic Eucalyptus globulus, E urophylla, Pinus elliottii, and P. radiata. Mycorrhiza. 2006c;16:251-9.

Courty PE, Buée M, Diedhiou AG, Frey-Klett P, Le Tacon F, Rineau F, Turpault MP, Uroz S, Garbaye J. The role of ectomycorrhizal communities in forest ecosystem processes: new perspectives and emerging concepts. Soil Biol Biochem. 2010;42:679-98.

Dickson A, Leaf AL, Hosner JF. Quality appraisal of white spruce and white pine seedling stock in nurseries. For Chron. 1960;36:10-3.

Empresa Brasileira de Pesquisa Agropecuária - Embrapa. Manual de métodos de análise de solo. $2^{\mathrm{a}}$.ed. Rio de Janeiro: Embrapa Solos; 2011.

Fernandes MCS, Costa LS, Grazziotti PH, Grazziotti DCFS, Santos JB, Rossi MJ. Pisolithus sp. tolerance to glyphosate and isoxaflutole in vitro. R Árvore. 2014;38:461-8.

Garbaye J. Utilisation des mycorhizes en sylviculture. In: Strullu DG, editor. Les mycorhizes des arbres et plantes cultivées. Paris: Lavoisier; 1990. p.197-250. 
Giovanetti MG, Mosse B. An evaluation of techniques for measuring vesicular-arbuscular mycorrhizal infection in roots. New Phytol. 1980;84:489-500.

Grazziotti PH, Siqueira JO, Moreira FMS. Espécies arbóreas e ectomicorrizas em relação ao excesso de metais pesados. Tópicos Ci Solo. 2003;3:55-105.

Instituto Nacional de Meteorologia - INMET. Normais Climatológicas do Brasil 1961-1990. Brasília, DF: Instituto Nacional de Meteorologia; 2009.

Köppen W. Klassification der klimate nach temperatur, niederschlag und jahreslauf. Petermanns Geogr Mitt. 1918;64:193-203.

Kuek C. Shake-flask culture of Laccaria laccata, an ectomycorrhizal basiodiomycete. Appl Microbiol Biotechnol. 1996;45:319-26.

Malavolta E, Vitti GC, Oliveira SA. Avaliação do estado nutricional das plantas: princípios e aplicações. $2^{\mathrm{a}}$.ed. Piracicaba: Potafos; 1997.

Oliveira LP, Rossi MJ, Furigo JRA, Silva Filho GN, Oliveira VL. Viability and infectivity of an ectomycorrhizal inoculum produced in an airlift bioreactor and immobilized in calcium alginate. Braz J Microbiol. 2006;37:251-5.

Rossi MJ, Furigo AJ, Oliveira VL. Inoculant production of ectomycorrhizal fungi by solid and submerged fermentations. Food Technol Biotechnol. 2007;45:277-86.
Silva RF, Antoniolli ZI, Andreazza R. Efeito da inoculação com fungos ectomicorrízicos na produção de mudas de Eucalyptus grandis Hill ex. Maiden em solo arenoso. Ci Flor. 2003;13:33-42.

Soares I, Borges AC, Barros NF, Bellei MM. Níveis de fósforo na formação de ectomicorrizas em mudas de eucalipto. $\mathrm{R}$ Bras Ci Solo. 1990;14:327-32.

Sousa NR, Franco AR, Oliveira RS, Castro PML. Ectomycorrhizal fungi as an alternative to the use of chemical fertilizers in nursery production of Pinus pinaster. J Environ Manage. 2012;95:269-74.

Souza EL, Antoniolli ZI, Machado RG, Eckhardt DP, Dahmer SFB, Schirmer GK. Effect of ectomycorrhizal fungi isolates inoculation in Eucalyptus grandis Hill ex Maiden seedlings development. Ci Flor. 2012;22:251-61.

Souza LAB, Bonnassis PAP, Silva Filho GN, Oliveira VL. New isolates of ectomycorrhizal fungi and the growth of eucalypt. Pesq Agropec Bras. 2008;43:235-41.

Souza LAB, Silva Filho GN, Oliveira VL. Eficiência de fungos ectomicorrízicos na absorção de fósforo e na promoção do crescimento de eucalipto. Pesq Agropec Bras. 2004;39:349-55.

Targhetta BL, Oliveira VL, Rossi MJ. Tolerância de fungos ectomicorrízicos e plantas associadas a níveis tóxicos de metais. R Árvore. 2013;37:825-33.

Vieira RF, Peres JRR. Definição do teor de fósforo no solo para máxima eficiência da associação micorrízica em Eucalyptus grandis. R Bras Ci Solo. 1988;12:237-41. 